石油技術協会誌 第 77 巻 第 2 号 （平成 24 年 3 月） $152 \sim 157$ 頁

Journal of the Japanese Association for Petroleum Technology

Vol. 77, No. 2 (March, 2012) pp. 152 157

\begin{tabular}{l} 
総 \\
Review \\
\hline
\end{tabular}

\title{
シェールガス開発における中国の動向
}

柳 小 正 ${ }^{*}$

(Received December 21, 2011 ; accepted January 26, 2012)

\section{Development trends for shale gas in China}

\section{Xiaozheng Liu}

Abstract : With recent years, the development of shale gas, which mining methods was not ever practical and economic viability was ever extremely poor, has been activated by technological advancements of countries including USA in recent years. China has more shale gas reserves than any other countries in the world. Expectation of shale gas development of China is growing.

In this paper discuss the development status and trends for shale gas in China. First, we reviewed the resources status and resources distribution of shale gas. Next, we explained development status and technology status. Finally, after mentioned above preferential policies and development plans by Chinese government, we examined shale gas development trends. China' s shale gas development, promote the commercialization and backup by Chinese government etc., will be considered further.

Keywords : China, shale gas, development trends, technology status, development plans, preferential policies

\section{1.はじめに}

シェールガス（shale gas）は非在来型エネルギー資源の 1つである。近年では, これまで採掘方法が実用化されて おらず，採算性も極めて贯かったシェールガス開発は，米 国の開発技術を適用することによって活発化し，天然ガス 供給の増加につながることも期待される。

中国のシェールガス資源量（resources）はかなり存在 すると認識され, 在来型エネルギーの補充源として重要視 されてきている。近年の中国では，米国など外国との協力 を含むシェールガスへの開発が展開してきている。また, 中国政府はシェールガス開発を促進させるため, 関連政策 などを提示している。こうしたことにより, 中国のエネル ギ一産業には大きな変化がもたらされると考えられる。

本稿では, シェールガス開発における中国の現状および 動向を論じることにする。まず，シェールガスの資源量， 分布状況を概観する。次に, 外国の企業との協力を含む シェールガスの開発状況および用いる開発技術を解説す る。最後に, 中国政府が提示した開発計画や優遇政策を述 ベた上で，シェールガスの開発動向を考察する。

\section{2. シェールガス資源量および分布状況}

\section{1 資 源 量}

世界におけるシェールガス資源量は豊富であると認識

\footnotetext{
*(制エイジアム研究所 Asiam Research Institute, Inc. 島根県立大学北東 アジア地域研究センター The University of Shimane Institute for North East Asian Research
}

されている。米国エネルギー情報局（Energy Information Administration, 以下, EIA）は2011 年 4 月，世界のシェー ルガスに関するレポートを公表した。これによると, 32 力国(EIA のレポートでは, 32 力国を 14 の地域を分けた) におけるシェールガスの確認埋蔵量（proved reserves）は, 2009 年には 6,622 兆 $\mathrm{cf}$ (約 185.4 兆 $\mathrm{m}^{3}$ ) と予測された。いつ ぽう, 世界の在来型天然ガスの確認埋蔵量は, 6,609 兆 cf (約 185.1 兆 $\mathrm{m}^{3}$ ) （2009 年末）である。こうしたことにより, 世界におけるシェールガスの資源量は，在来型天然ガスの 資源量に劣らない多さを有していると考えられる。

また，EIAによると，中国はシェールガス資源に恵まれ， シェールガス埋蔵量が世界的に最も多い国と評価された。

表 1 世界主要国の天然ガス資源量の評価（2009 年）

\begin{tabular}{|c|c|c|}
\hline & $\begin{array}{c}\text { 在来型天然ガス } \\
\text { 確認埋蔵量 }\end{array}$ & $\begin{array}{l}\text { シェールガス } \\
\text { 確認埋蔵量 }\end{array}$ \\
\hline 中 国 & 3.0 & 35.7 \\
\hline 米 国 & 7.6 & 24.1 \\
\hline アルゼンチン & 0.4 & 21.7 \\
\hline メキシコ & 0.3 & 19.1 \\
\hline 南アフリカ & - & 13.6 \\
\hline オーストラリア & 3.1 & 11.1 \\
\hline カナダ & 1.7 & 10.9 \\
\hline リビア & 1.5 & 8.1 \\
\hline アルジェリア & 4.5 & 6.5 \\
\hline ブラジル & 0.4 & 6.3 \\
\hline
\end{tabular}

出所 : World Shale Gas Resources:An Initial Assessment of 14 Regions Outside the United States により作成 
中国におけるシェールガスの確認埋蔵量は 1,275 兆 $\mathrm{cf}$ (約 35.7 兆 $\mathrm{m}^{3}$ ) で，評価した 32 力国に占める割合が約 2 割を 占めている。第二位は米国 862 兆 $\mathrm{cf}\left(\right.$ 約 24.1 兆 $\mathrm{m}^{3}$ ) であり, 以下，アルゼンチン 774 兆 $\mathrm{cf}\left(\right.$ 約 21.7 兆 $\left.\mathrm{m}^{3}\right)$, メキシコ 681 兆 $\mathrm{cf}\left(\right.$ 約 19.1 兆 $\mathrm{m}^{3}$ )，と続いている。

いつぽう，中国では，シェールガス資源への評価が始め られているものの，現在の段階では，シェールガス資源 への探査は模索段階にあり, 在来型資源のようなポテン シャルに対する全面的な評価はいまだに行われていない。 シェールガス資源の評価の方法としては，中国と米国の地 質資料の対比を実施し，中国のシェールガス資源量を推定 するものである。その結果，中国におけるシェールガス 資源量は 100 兆 $\mathrm{m}^{3}$, シェールガスの確認埋蔵量は $15 \sim 30$ 兆 $\mathrm{m}^{3}$ であると推定されている。

近年, 中国の一部地域においてシェールガス資源調査が 行われている。特に，四川盆地（四川省，重慶市）で資源 調査の初期調査の結果，同盆地には巨大なシェールガスの 資源量があると判断されている。例えば，四川盆地の寒武 系統筑竹寺組におけるシェールガスの資源量は $7.1 〜 14.6$ 兆 $\mathrm{m}^{3}$ であり, 同盆地の在来型資源量の 7.2 兆 $\mathrm{m}^{3}$ と比べ魅 力的である。

以上で示したように，中国のシェールガス資源量は，米 国の評価でも中国の評価でも豊富であると認識されてい る。今後の本格的なシェールガスの開発が期待されると考 えられる。

\section{2 分布状況}

中国では，シェールガス資源量を推定するとともに, シェールガスの賦存範囲を評価している。中国のシェール ガスが広範囲に分布し，また，シェールガスの生成条件に は多様性があり，海相地層，海相・陸相重畳地層，陸相地 層などでシェールガスの賦存は認められている。シェール ガスの貯留面積については，海相地層の貯留面積は 300 万 $\mathrm{km}^{2}$ ，陸相・海相重畳地層の貯留面積は 200 万 $\mathrm{km}^{2}$ ，陸相
表 2 地域別シェールガス総資源量に含める割合

\begin{tabular}{|l|c|}
\multicolumn{2}{c}{} \\
\hline & 単位 : \% \\
\hline 南方区 & 46.8 \\
\hline 北方区 & 8.9 \\
\hline 西北区 & 43.0 \\
\hline 青海チベット区 & 1.3 \\
\hline
\end{tabular}

出所：中国鳳凰網の報道により作成

地層の貯留面積は 280 万 $\mathrm{km}^{2}$ と推測されている。

地域別シェールガス資源の評価は, 南方区, 北方区, 西 北区，青海チベット区に分けて行われた。初歩的な評価の 結果，南方区はシェールガス総資源量の $46.8 \%$ を占めてお り, シェールガスの重要な賦存地であると判断された（図 1, 表 2)。特に, 南方区における四川省南部, 四川省東部, 重慶市東南部, 貴州省北部など上陽子地域は, シェールガ ス資源に恵まれ，シェールガスの主要な探査・開発地域と されている。

\section{3. シェールガスの研究・開発動向}

中国では 2004 年以降, 米国のシェールガス開発の成功 経験を機にし，シェールガスの開発に大きな関心を寄せ, シェールガスをめぐる研究・探査などの活動は活発化して きている。国土資源部油気資源戦略研究センター（以下, 研究センター), 中国地質大学 (北京), 中国石油天然気集 団公司 (以下, CNPC), 中国石油化工集団公司（以下, Sinopec) など官学民は, シェールガスの研究・開発プロジェ クトを実施している。以下では, こうした研究・開発動向 を考察する。

3.1 政府系の研究・開発プロジェクト

研究センターは 2004 年, 中国地質大学（北京）と研究 チームを設立し, シェールガス資源の研究・開発作業を開 始した。同チームは, 湖南省, 四川省など 8 省・直轄市の 鉱床生成条件を米国のシェールガスの地質資料と対比し,

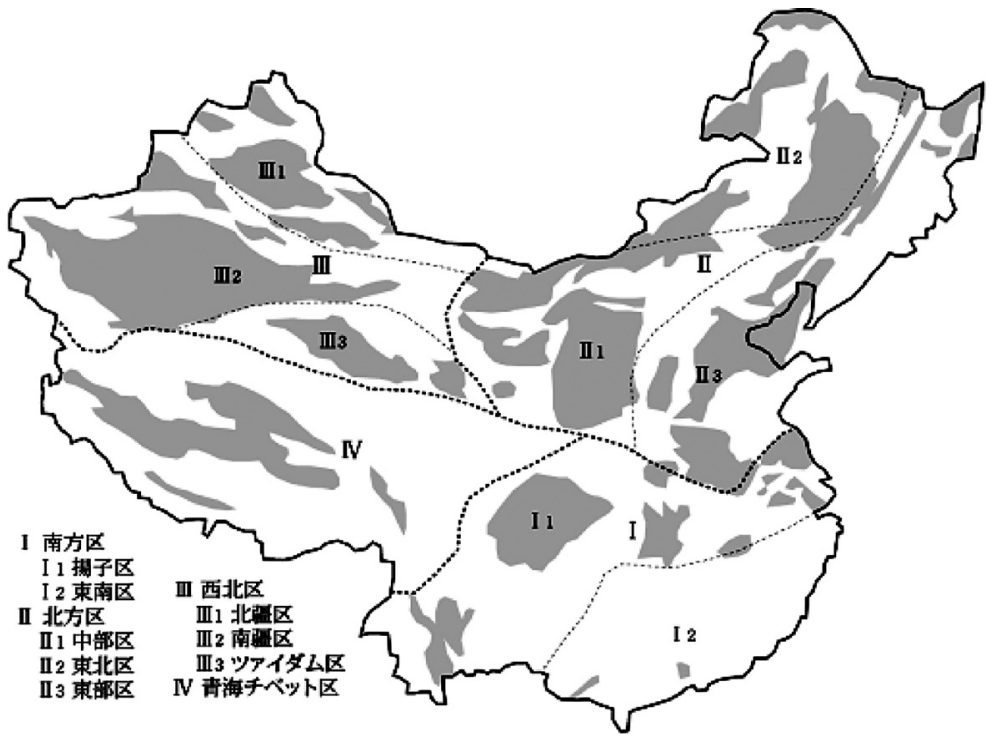

出所 : 張 金川, 2008

図 1 中国におけるシェールガスの分布状況 
シェールガスの評価を行つた。その結果, 重慶市の南部地 域および東南部地域のカンブリア紀前期, シルル紀前期, 二畳紀中期の 3 つの地層では, シェールガスが広く分布し, 大規模なシェールガス形成の可能性があると推測された。

また, 研究センターは 2008 年, 中国地質大学（北京） のほかに，CNPC に加えて研究チームを立上げ，シェール ガスの賦存が有望とされる地域を重点的に調査・研究した。 今回, 調査 - 研究した地域は, 四川盆地, 松遼盆地（黒竜 江省と吉林省）および中・下陽子地域（中陽子地域: 四川 省, 湖南省, 湖北省, 河南省, 江西省の一部。下陽子地域: 安徽省, 江西省東部, 江蘇省 -上海市 - 浙江省の一部) で あった。これらの地域における古生界海相のシェール層を 重点的に調査・研究した。

2009 年 8 月, 調查・研究の結果を基づいて重慶市（東 南部の彭水県）で，シェールガス資源の探査プロジェクト は実施された。同年 11 月に掘削した結果, シェールガス が確認された。このプロジェクトは $3 \sim 5$ 年間で実施され る予定であり，さらなる調査を行う。

2010 年 7 月, 国土資源部は重慶市を含むいくつの国家 級シェールガス先導試験開発区を確定した。2010 年 7 月 2 日付の『中国環境報』によると, 確定された国家級シェー ルガス先導試験開発区は, 四川省南部, 貴州省北部, 重慶 市東南部, 重慶市東北部など 7 つがある。開発を進めるた め, 国土部資源部は 2011 年 4 月, 重慶市の渝黔南川, 渝 黔湘秀山, 貴州省の貴州綏陽, 貴州鳳鳥の 4 力所にある シェールガス鉱区の探鉱権入札を決定した。

地方の有力企業も, 政府が主導したシェールガス開発プ ロジェクトの参加を検討している。例えば, 重慶市の重 慶能源集団は渝東南, 渝東北などの 5 県・区に分布した約 1,000 億 $\mathrm{m}^{3}$ のシェールガスを開発する予定である。重慶 能源集団は目標区 $10 \sim 15$ 力所，探査開発区 $5 \sim 8$ 力所を 選定し, 2015 年までに, 確認埋蔵量 1,000 億 $\mathrm{m}^{3}$ を達成し, 生産能力 $30 \sim 50$ 億 $\mathrm{m}^{3}$ を実現する計画を立てている。

\section{$3.2 \mathrm{CNPC}$ の開発動向}

2006 年, CNPC に所属している中国石油探査開発研究 院は，四川盆地西南部の地域でシェールガス資源の調査を 行った。1 年間の現地調査と解析を実施したが，良好な結 果は得られなかつた。

2008 年 11 月, CNPC は四川省宜賓市において, シェー ルガスのサンプル調査を実施した。掘削坑井の計画深度は $200 \mathrm{~m}$ であり, $154 \mathrm{~m}$ の地点でシェールガスのコアサンプ ルを採取した。また，有機物の含有率などの鉱物分析に約 200 サンプル，シェールに吸着したガスの分析用に 14 サ ンプルを取得, 780 力所で GR 值 (ガンマ線) 測定を行った。

また, 2009 年 12 月, CNPC は, 四川省威遠ガス田にお いてシェールガス調査井威 201 井を掘削した。2009 年 12 月から 2010 年 3 月にかけて, $2,851 \mathrm{~m}$ の深度まで掘削され たが, 調査の結果は公表されていない。いっぽう, 威遠ガ ス田は, 1965 年に生産を開始した在来型ガス田である。 威 5 井は, 1996 年に掘削した時にシェールガスを確認し ており，2006 年に再度掘削し，カンブリア層でテストを
行つた結果, シェールガスの集積層を発見した。

この結果を受け, CNPC は続いて, 四川盆地でシェール ガスの探査を行っている。2010 年の 4 月, CNPC 傘下の 中国石油川慶物理探鉱公司は, 四川盆地の相関鉱区で嘉 陵江，飛仙関，侏羅系の 3 つ試験地において地質資料の採 取を完了し, 四川盆地におけるシェールガスの発見のため の基礎調査に着手した。

2010 年 4 月, CNPC は四川省珙県でシェールガス鉱床 を発見した。中国石油川慶物探公司は 2009 年, 同地域で 地震探査を行い, 地質資料により, 地下頁岩系構造に天然 ガス鉱床を発見した。寧 201 井を掘削した結果, 同坑井の シェールガス埋蔵量は 600 万 $\mathrm{m}^{3}$ 以上に達しているとして いる。

CNPC は 2011 年まで, 四川盆地南部で約 20 坑井を掘削 した。注目されるのは 2011 年 3 月に掘削した威 201-H1 井 である。同坑井は, 中国における初のシェールガス水平坑 井（深度：2,832 m, 水平部：1,079 m) である。また, 同 年 7 月, 11 段階のフラクチャリングが行われた。これは, 中国で初のシェールガス水平坑井の掘削および水平坑井に おけるフラクチャリングの実施で, 中国のシェールガス開 発における大きな意味を持つといえる。

\subsection{Sinopec $の$ 開発動向}

Sinopec は 2008 年以降, シェール・ガスを含む非在来型 石油・天然ガスの探査事業を全面的に展開している。2010 年 4 月, Sinopec 傘下の華東石油局は, シェールガスの探査・ 掘削を実施した。 5 月, 安徽省南部の宣 1 坑井が掘削され た。また, 華東石油局のいくつかの探物理査チームは, 山 西省，陝西省，貴州省などで地質資料の採取を行い，2010 年 4 月から 6 月にかけて $2,327 \mathrm{~km}$ の二次元地震探査を実 施した。

いつぽう, Sinopec 傘下の中原油田は 2010 年 5 月, 貴州 省大方県の超大型シェールガス坑井である方深 1 井におい て，初のフラクチャリングを実施した。方深 1 井のフラク チャリング実施に当たって, $2,121 \mathrm{~m}^{3}$ のフラクチャリング 流体，270トンの砂を圧入した。なお，同フラクチャリン グは米国 Schlumberger 社の技術協力により行われたもの である。

また, 2010 年 6 月, Sinopec 傘下の勘探南方分公司は シェールガス勘探項目部を設立し, 南方地域における シェールガス資源の潜在力および鉱区評価を行なうことに なつた。勘探南方分公司は 2010 年 12 月まで, 四川省東北 部の元壩地域, 四川省東南部の涪陵地域で 18 坑井を掘削 し，ガス流を得た。特に，2010 年 12 月に元壩地域の元壩 -9 井では, 日量約 11.5 万 $\mathrm{m}^{3}$ のシェールガスの産出が確認 された。続いて, 2011 年 11 月, 元壩地域で元頁 HF-1 水 平坑井を掘削した。同水平井の深度は $4,897 \mathrm{~m}$, 水平部の 長さは 1,050 m である。

さらに, Sinopec は国土部が主宰するシェールガス開発 プロジェクトに参加している。2011 年 8 月, Sinopec は国 土部の渝黔南川ブロックを落札した。Sinopec は渝黔南川 ブロックにおいて, 評価井など 11 坑井を掘削し, 総探査 
費用に 5.9 億元投入する予定である。

今後, Sinopec は更なるシェールガスを含む非在来ガス の開発を進め, 2015 年には非在来ガスの年産 25 億 $\mathrm{m}^{3}$ 以 上の生産能力を確立しようとしている。

\section{4 外国との協力状況}

中米両国は 2009 年 11 月, オバマ大統領の訪中時, シェー ルガスの共同研究を進めることで合意した。また，それ に先立って，中米両国は 2009 年 9 月に開催された第 4 回 中米エネルギー政策対話や第 9 回中米石油・天然ガス産業 フォーラムを通じ，中国の非在来天然ガス資源開発を加速 すること, 中米両国シェールガス協力イニシアチブを開始 することについて合意した。

中米両国のシェールガス資源協力イニシアチブの主な内 容は次のとおりである。1）米国内で得られた経験を活か して中国のシェールガス資源ポテンシャルを評価する。 2）シェールガス資源の環境持続的な開発を推進する。3) 中国内のシェールガス資源開発を加速するために共同で技 術調査を行う。4）米中石油・ガス業界フォーラムやワー クショップなどを通して中国内でのシェールガス投資を促 進する。

また，2010 年 5 月 25 日の米中戦略経済対話では，中米 両国は『中米シェールガス資源作業グループ活動計画』に 調印した。この中で，2010 年 9 月に米国で開催予定の中 米油・ガス産業フォーラムにおいて，シェールガス開発が 議論されるほか，シェールガスフィールドの見学を行うな ど具体的な協力について合意した。

いつぽう，外国企業との協力について，2009 年 9 月, 中米エネルギー政策対話および第 9 回中米石油・天然ガス 産業フォーラムの期間中, CNPC は米国の石油会社である ConocoPhillips との間で，中国のシェールガスに関する協 力開発意向書に署名した。同年 11 月, CNPC と Shell は北 京において, 『滀順－永川鉱区シェールガス共同評価協 議』に調印した。富順一永川鉱区は四川盆地西南部に位置 し，その面積は約 $4,000 \mathrm{~km}^{2}$ である。このプロジェクトは， CNPC に所属している西南油気田公司がオペレータとし,
Shell の専門家とともに進める。

その後, 2010 年 4 月, CNPC と Shell は四川省長寧県で, 調査坑井（寧 201 井）を掘削した。掘削予定深度は 2,830 m である。また, CNPC が Shell と協力して開発した坑井 は陽 101 井（掘削深度：3,755 m) で, 生産量は 1 日あた り 5 万 $\mathrm{m}^{3}$ である。

いつぽう, Sinopec も外国の企業と協力してシェールガ スを開発している。2010 年 1 月, Sinopec と BP は中国に おけるシェールガスの共同開発に合意したと発表した。 開発地域として, 貴州省凱里の $2,000 \mathrm{~km}^{2}$ と江蘇省黄橋の $1,000 \mathrm{~km}^{2}$ の協力鉱区を暫定的に選定した。この協定は, シェールガス開発分野で Sinopec の初の外国との協力プロ ジェクトである。これは，2009 年に CNPC と Shell の間の シェールガス協力開発協議に続く, 外国企業との大きな協 力開発の進展と考えられる。

また, Sinopec 傘下の勘探南方分公司は 2011 年 7 月, ExxonMobil との間で, 『川西南五指山地区におけるシェールガス 聯合研究協議』を締結した。聯合研究地域の面積は 3,643 $\mathrm{km}^{2}$, 協議の内容は二次元地震探査および地震探査資料の 解釈, シェールガス鉱床の特徵, シェールガス資源量の試 算などを含める。

以上のシェールガス調査・開発の動向によれば，中国の シェールガス資源の開発は依然模索段階にあり，シェール ガス資源量に対する総合的な評価はいまだに進められてい ない。今後も, 中国の開発企業は引き続き外国企業と協力 し，シェールガスの商用化・実用化へ向けて進展していく と考えられる。

\section{4. シェールガスの開発技術}

シェールガスの開発技術は広範囲にわたるが，ここでは 掘削技術，生産・増産方式を中心として考察する。また， 考察にあたつて, シェールガスの開発技術を説明しながら, 中国と外国の技術との対比を行う。

\section{1 掘削技術}

これまでは, 垂直坑井の掘削はシェールガス開発に使用

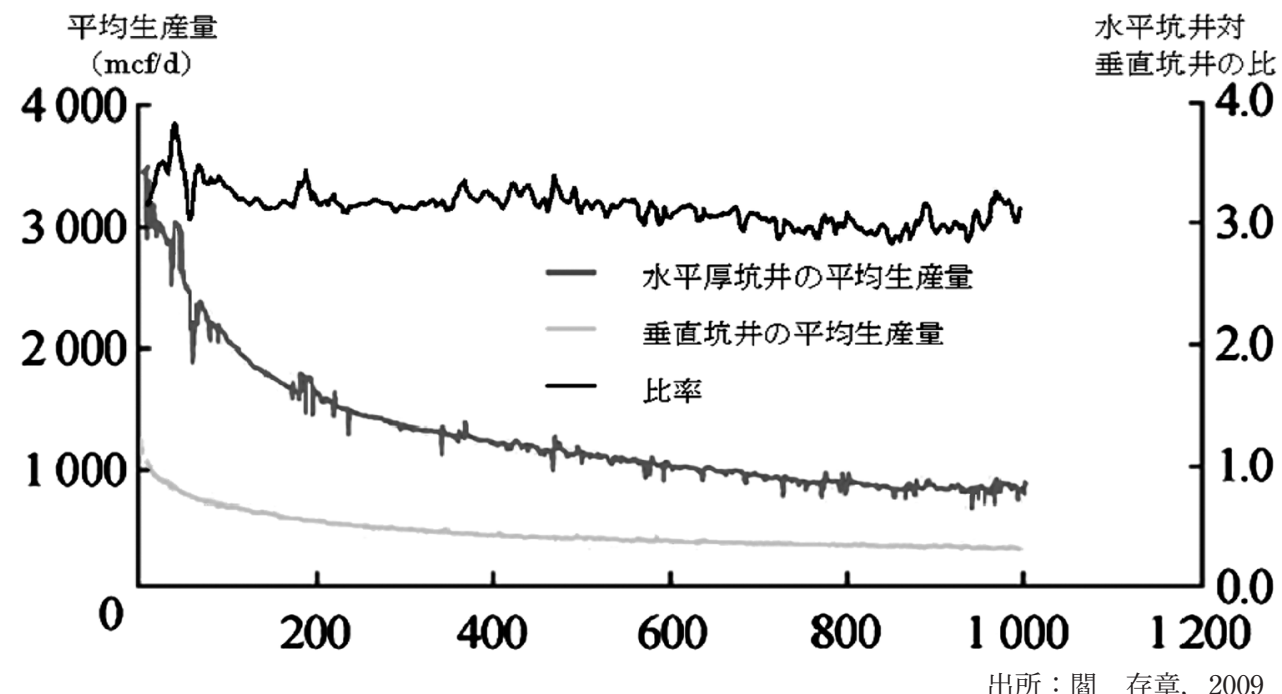

図 2 米国における水平坑井と垂直坑井の平均生産量比較 
される掘削方法であったが, 現在, 水平坑井が広範囲に利 用され，主な掘削方式とされている。水平坑井掘削法は， 貯留層との接触面積が垂直坑井に比べて拡大するため, 生 産量が大幅に増大することが期待できる掘削方法である。 水平坑井の掘削コストが垂直坑井の $1 \sim 1.5$ 倍に対し, 水 平坑井の生産量は垂直坑井の約 3 倍である (図 2)。さらに, 1 つの坑井から複数の水平部分をもつマルチテラル坑井も 出現している。

中米両国は，シェールガス掘削技術のギャップがある。 米国では, 2002 年までシェールガス開発に当たつて垂直 坑井掘削が適用されていたが，2002 年以降，水平坑井開 発の成功を受け, 水平坑井掘削技術を用いて掘削されてい る。いつぽう, 中国のシェールガス掘削技術について, 現 在段階のシェールガス開発は垂直坑井の掘削がほとんど で, 水平坑井の掘削は 2011 年末時点, わずか 2 坑井である。

\section{2 生産・増産方式}

シェールガスは, 吸着あるいは遊離状態で頁岩（シェー ル）の層中に貯蔵されている天然ガスである。頁岩の浸透 率が $0.001 〜 2 \mathrm{md}$ と極めて低いため, 貯留岩とはならず, シェールガス生産の経済性は在来型天然ガスより低い。こ のように, シェールガスは, 同じ天然ガスでも頁岩層に閉 じ込められ, 地層内でガスが移動できないために坑井を掘 削しても経済性を満たすガス量を生産することができない。

シェールガスの生産性を向上させるためには採取技術の 工夫が必要である。シェールガスの生産量確保には従来型 よりも多くの坑井数を要する。また, 少数の良好なフラク チャーを持っている集積層を除いて，一般的にシェールガ スはフラクチャリングが実施された後, 商業開発の価值が 出てくる。

最近では, 水平坑井の水平部分で多段階フラクチャリン グが適用されている。水平坑井の多段階フラクチャリング が実施されると, シェールガスの採収率はさらに高くなる。 米国では, シェールガス開発にあたつて, 基本的に水平坑 井で多段階フラクチャリングが実施されている。現在, 米 国の多段階フラクチャリング技術は，32 段階までのフラ クチャリングを実施することが可能である。

中国のフラクチャリングの実施状況に関して, Sinopec は 2010 年 5 月, 貴州省大方県の方深 1 井（深度: 6,950 m) で，初めてフラクチャリングを実施した。しかし，方深 1 井におけるフラクチャリングの実施は, Sinopecが独自に 行ったものではなく，米国の Schlumberger との協力によ るものである。また，多段階フラクチャリング技術につい て, 現在の段階では, 中国の企業は 11 段階フラクチャリ ングを実施している。

以上では，中国のシェールガス開発技術（掘削技術，生 産・増産方式）を概観した。中国のシェールガス開発は, まだ習得の段階であり，技術の確立がなされていないと考 えられる。いつぽう, シェールガス開発をめぐる技術につ いて, 水平坑井, フラクチャリングを含む以下のような課 題が提示され，これらの技術の確立はシェールガス開発に おいて不可欠とされている。
・シェールガスの総合的な地質学的評価手法

・シェールガスの目的インターバルの選択手法

・ビッグホール穿孔技術

・水平坑井の掘削技術

・水平坑井のフラクチャリング技術

・掘削および仕上げ技術

・地震探査データの処理技術

・マイクロ地震探査モニタリング技術

\section{5. 開発計画および優遇政策}

\section{1 開発計画}

中国政府はシェールガス資源の開発を重視している。 「シェールガス第 12 次 5 力年 $(2010 \sim 2015$ 年）規画」（以 下，十二五規画）では，2015 年までシェールガス資源量 の調査と評価を基本的に完成させる。また, 中国の地質条 件に合うシェールガス開発の体系化，開発技術規範および 標準を策定する。

十二五規画では，主な開発地域を示している。これらの 開発地域として四川省, 重慶市, 山西省, 遼寧省などは重 点的な開発省・市が挙げられている。また，鄂西渝東，川 西, 川東北, 渝黔南川など 19 区域は, 重点的な開発ブロッ クとしている。

また，十二五規画では，具体的なシェールガスの開発 指標が示されている。すなわち, 二次元地震探査が 4.3 万 $\mathrm{km}$, 三次元地震探査が $4,300 \mathrm{~km}^{2}, 50$ 坑の調査坑井, 150 坑の各種試掘坑井, 990 坑の水平坑井の掘削が実施さ れる。結果として, シェールガスの予測埋蔵量 (possible reserves) 1 兆 $\mathrm{m}^{3}$, 確認埋蔵量 2,000 億 $\mathrm{m}^{3}$, 年間生産量 65 億 $\mathrm{m}^{3}$ に達するとしている。

\section{2 優遇政策}

2011 年 12 月 8 日付の『上海証券報』によると, 中国政 府はシェールガス開発に関する政策を定め, 間もなく発表 されるとしている。ここでは，シェールガスに対する補助 金政策をほぼ確定したと述べている。基本的には，炭層义 タンガス開発向けの助成政策に準じた政策がシェールガス にも適用されるとのことである。

また, シェールガスの開発を促進するため, 中国政府は 大幅に規制を緩和し，多様な企業に参加認める方針を採つ ている。シェールガスの開発政策は, 今までの在来型石油・ 天然ガス, 炭層ガスと違い, 多くの投資主体がシェールガ スの探査・開発に参入することを奨励している。

以上のように, シェールガスの計画面においては, 中国 政府は，重点的な開発地域を示し，具体的な開発指標を提 出した。また, シェールガス開発を促進させるため, 大幅 に規制を緩和する。こうしたことから, 中国政府はシェー ルガス開発を重要な位置に置き，シェールガスをエネル ギーの供給源として期待していと考えられる。

\section{6. まとめ}

以上では，シェールガス開発における中国の資源状況， 開発動向, 開発技術, 開発計画などについて考察した。こ 
れらの考察により, 以下のことが明らかになった。

（1）中国におけるシェールガス確認埋蔵量は，世界で最も 多い国と評価されている。また，中国のシェールガス 確認埋蔵量は, 中国の在来型天然ガス資源量を大幅に 超えると推定されており，エネルギーの供給源として 重要視されている。

（2）近年の中国では, 外国企業との協力を含むシェールガ スの開発が活発している。今後も化石燃料の需要増が 確実に見込まれる中で, シェールガスへの期待は高ま り，開発も加速度的に進むことが想定される。

（3）中国のシェールガスの開発技術はまだ不十分である。 中国の開発企業はシェールガスの開発技術を習得する ため，今後とも，引き続き外国企業との協力が必要で あると考えている。

（4）中国政府はシェールガス開発を重要な位置に置いてい る。シェールガスの開発を促進するため, 優遇政策を 制定し, まもなく発表される。また, 十二五規画では, 具体的な開発指標を提出している。シェールガスの開 発により, 今後における中国の天然ガス供給は大幅に 増加すると期待される

\section{参考文献}

柳 小正, 2001: 中国における炭層ガスの開発, 石油技術 協会・石技誌, 76(4), 321-328.

張 金川ほか, 2008 年 6 月：中国頁岩気資源勘探潜力, 天然気工業，136-140.

李 健忠ほか, 2009 年 5 月: 中国頁岩気資源前景与戦略地 位, 天然気工業, 11-16

閻 存章ほか, 2009 年 5 月：頁岩気是潜力巨大的非常規 天然気資源, 天然気工業, - - 6 .

黄 玉珍ほか, 2009 年 5 月：技術進歩是推動美国頁岩気 快速発展的関鍵, 天然気工業, 7-10.

http://paper.people.com.cn/zgnyb/html/2009-12/07/ content_398912.htm(cited 2010/01/10)

http://www.lrn.cn/media/energynews/oil/201001/ t20100119_454205.htm(cited 2010/01/19)

http://www.gov.cn/gzdt/2010-01/29/content_1522372. htm(cited 2010/01/30)

http://news.cnpc.com.cn/system/2009/11/27/001266414. shtml(cited 2010/01/30)

http://www.gov.cn/gzdt/2010-01/29/content_1522372.htm (cited 2010/01/30)

http://www.mlr.gov.cn/xwdt/jrxw/200908/t20090825_124466. htm (cited 2010/01/30)

http://news.cnpc.com.cn/system/2010/03/24/001281953. shtml) (cited 2010/03/25)

http://www.gov.cn/ztzl/2008-12/02/content_1165808.htm) (cited 2010/03/25)

http://www.china5e.com/show.php?contentid=90512(cited 2010/04/15)

http://www.shbtp.com.cn/index/wdetail?id=1095017 (cited 2010/05/12)

http://www.pbnews.com.cn/system/2010/05/18/001289294. shtml(cited 2010/05/18)

http://news.xinmin.cn/rollnews/2010/05/26/4983931. html(cited 2010/05/26)

http://news.xhby.net/system/2010/05/28/010760857. shtml(cited 2010/05/28)

http://www.sinopecnews.com.cn/shnews/content/2010-06/01/ content_822117.htm) (cited 2010/06/01)

http://www.china5e.com/show.php?contentid=109451 (cited 2010/07/02)

http://www.china5e.com/show.php?contentid=109451 (cited 2010/07/02)

http://www.eia.gov/analysis/studies/worldshalegas/(cited 2011/10/12)

http://www.worldoilweb.com/info/917080.shtml(cited 2010/12/25)

http://china.cippe.net/news/16949.htm(cited 2011/06/12)

http://www.nfsinopec.com.cn/content.aspx?new id $=957($ cited 2011/07/12)

http://www.mlr.gov.cn/xwdt/jrxw/200908/t20090825_124466. htm(cited 2011/08/08)

http://www.cippe.net/news/html/201108/51385.html(cited 2011/08/12)

http://www.ccstock.cn/stock/redian/2011-08-19/A543473. html(cited 2011/08/19)

http://gtt.xinjiang.gov.cn/10040/10060/10003/10004/2011/2 4515.htm(cited 2011/12/03)

http://news.chinaiiss.com/html/201112/8/a4512c_2. html(cited 2011/12/08) 